INEL-94/0159

\title{
Monitoring Plan for Routine Organic Air Emissions at the Radioactive Waste Management Complex Waste Storage Facilities
}

\author{
DISCLAIMER
}

This report was prepared as an account of work sponsored by an agency of the United States Government. Neither the United States Government nor any agency thereof, nor any of their employees, makes any warranty, express or implied, or assumes any legal liability or responsibility for the accuracy, completeness, or usefulness of any information, apparatus, product, or process disclosed, or represents that its use would not infringe privately owned rights. Reference herein to any specific commercial product, process, or service by trade name, trademark, manufacturer, or otherwise does not necessarily constitute or imply its endorsement, recommendation, or favoring by the United States Government or any agency thereof. The views and opinions of authors expressed herein do not necessarily state or reflect those of the United States Government or any agency thereof.

Published June 1994

\section{Idaho National Engineering Laboratory Lockheed Idaho Technologies Company Idaho Falls, Idaho 83415}

\section{Prepared for the}

U.S. Department of Energy Office of Environmental Management Under DOE Idaho Operations Office Contract DE-AC07-94ID13223 


\section{DISCLAIMER}

Portions of this document may be illegible in electronic image products. Images are produced from the best available original document. 


\section{Monitoring Plan \\ for Routine Organic Air Emissions \\ at the Radioactive Waste Management Complex \\ Waste Storage Facilities}

Prepared by:

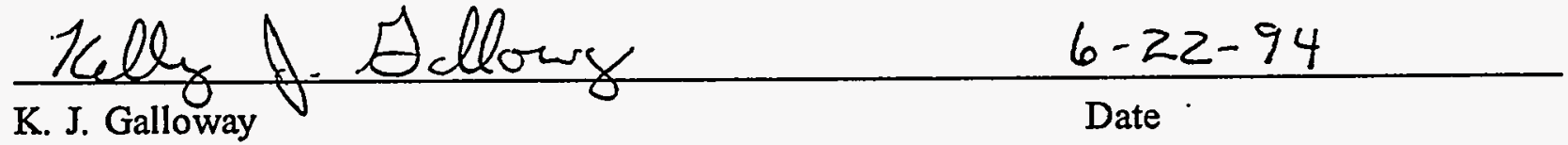

Mechanical Engineering Unit

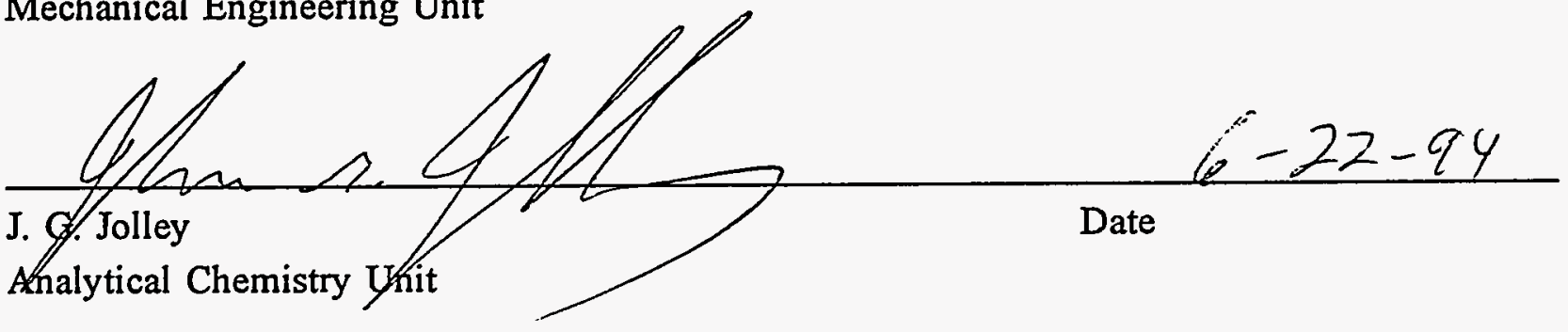




\begin{abstract}
This monitoring plan provides the information necessary to perform routine organic air emissions monitoring at the Waste Storage Facilities located at the Transuranic Storage Area of the Radioactive Waste Management Complex at the Idaho National Engineering Laboratory. The Waste Storage Facilities include both the Type I and II Waste Storage Modules. The plan implements a dual method approach where two dissimilar analytical methodologies, Open-Path Fourier Transform Infrared Spectroscopy (OP-FTIR) and ancillary SUMMA® canister sampling, following the U. S. Environmental Protection Agency (EPA) analytical method TO-14, will be used to provide qualitative and quantitative volatile organic concentration data.
\end{abstract}

The Open-Path Fourier Transform Infrared Spectroscopy will provide in situ, real time monitoring of volatile organic compound concentrations in the ambient air of the Waste Storage Facilities. To supplement the OP.FTIR data, air samples will be collected using SUMMA®, passivated, stainless steel canisters, following the EPA Method TO-14. These samples will be analyzed for volatile organic compounds with gas chromatograph/mass spectrometry analysis. The sampling strategy, procedures, and schedules are included in this monitoring plan.

The development of this monitoring plan is driven by regulatory compliance to the Resource Conservation and Recovery Act, State of Idaho Toxic Air Pollutant increments, Occupational Safety and Health Administration. The various state and federal regulations address the characterization of the volatile organic compounds and the resultant ambient air emissions that may originate from facilities involved in industrial production and/or waste management activities. 


\section{CONTENTS}

ABSTRACT $\ldots \ldots \ldots \ldots \ldots \ldots \ldots \ldots \ldots \ldots \ldots \ldots \ldots \ldots \ldots \ldots \ldots \ldots \ldots \ldots \ldots$ iii

ACRONYMS $\ldots \ldots \ldots \ldots \ldots \ldots \ldots \ldots \ldots \ldots \ldots \ldots \ldots \ldots$ viii

1. PROJECT DESCRIPTION $\ldots \ldots \ldots \ldots \ldots \ldots \ldots \ldots \ldots \ldots \ldots \ldots \ldots \ldots \ldots \ldots \ldots$

2. PROJECT ORGANIZATION AND RESPONSIBILITIES $\ldots \ldots \ldots \ldots \ldots \ldots 3$

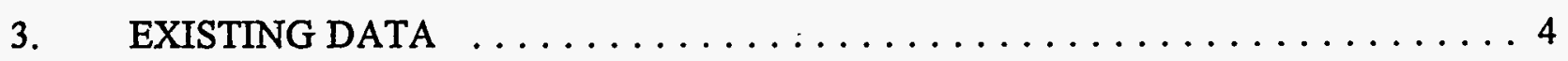

$3.1 \quad$ Existing Site Information $\ldots \ldots \ldots \ldots \ldots \ldots \ldots \ldots \ldots \ldots$

3.2 Analysis of Existing Data $\ldots \ldots \ldots \ldots \ldots \ldots \ldots \ldots \ldots$

4. QUALITY ASSURANCE OBJECTIVES AND MONITORING STRATEGY . . . 6

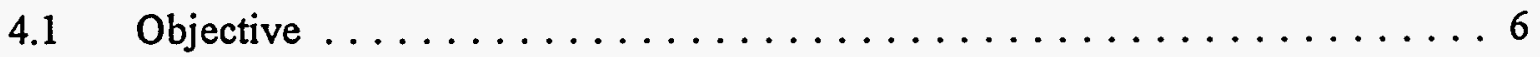

4.2 Data Quality Objectives $\ldots \ldots \ldots \ldots \ldots \ldots \ldots \ldots \ldots$

4.2.1 Analytical Levels $\ldots \ldots \ldots \ldots \ldots \ldots \ldots \ldots \ldots \ldots$

4.2.2 Data Completeness, Representativeness, and Comparability . . . . . 8

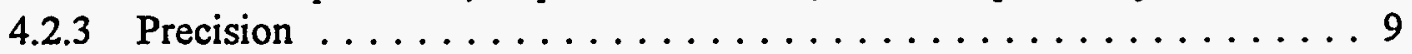

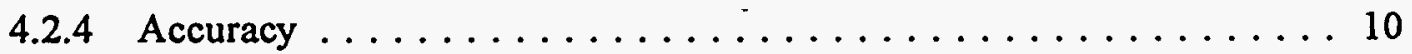

4.3 Monitoring Strategy and Design $\ldots \ldots \ldots \ldots \ldots \ldots \ldots \ldots \ldots \ldots$

4.3.1 OP-FTIR Monitoring $\ldots \ldots \ldots \ldots \ldots \ldots \ldots \ldots \ldots \ldots$

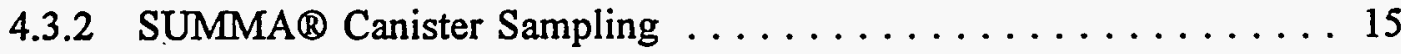

4.3.3 Portable Gas Chromatograph Sampling ............. 16

4.3.4 Quality Assurance/Quality Control Samples ............ 16

5. MONITORING AND SAMPLING PROCEDURES $\ldots \ldots \ldots \ldots \ldots \ldots \ldots$

5.1 Monitoring and Sampling Preparation $\ldots \ldots \ldots \ldots \ldots \ldots \ldots$

$5.2 \quad$ OP-FTIR Monitoring $\ldots \ldots \ldots \ldots \ldots \ldots \ldots \ldots \ldots \ldots \ldots \ldots \ldots \ldots$

5.2.1 OP-FTIR Operation Procedures $\ldots \ldots \ldots \ldots \ldots \ldots \ldots \ldots \ldots$

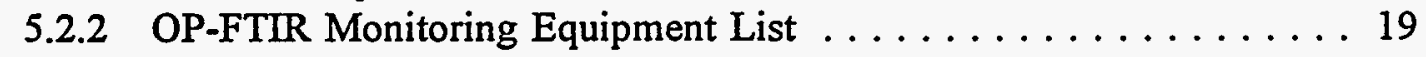

$5.3 \quad$ SUMMA® Sampling, Method TO-14 . . . . . . . . . . 19

5.3.1 Sample Collection $\ldots \ldots \ldots \ldots \ldots \ldots \ldots \ldots \ldots \ldots \ldots \ldots$ 


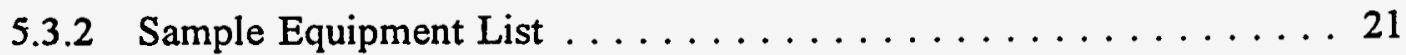

5.3.3 SUMMA® Canister Maintenance/Decontamination ......... 21

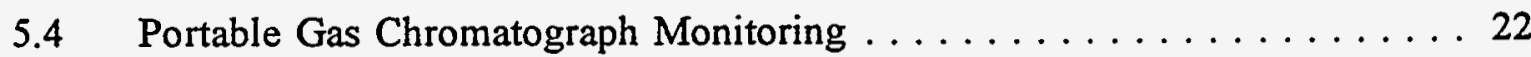

6. DOCUMENT MANAGEMENT AND SAMPLE HANDLING $\ldots \ldots \ldots \ldots \ldots 23$

6.1 Pre-Monitoring and Sampling Documentation $\ldots \ldots \ldots \ldots \ldots \ldots$

6.2 Monitoring and Sampling Documentation $\ldots \ldots \ldots \ldots \ldots \ldots$

6.2.1 Sample Container Tag . . . . . . . . . . . . . . 23

6.2 .2 Sample Identification Number $\ldots \ldots \ldots \ldots \ldots \ldots \ldots \ldots . \ldots \ldots$

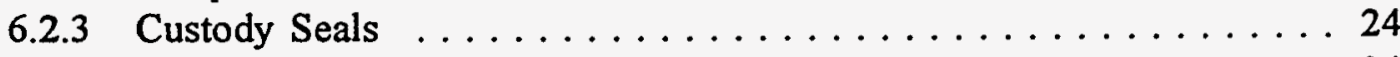

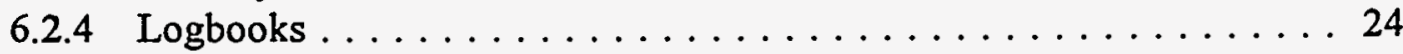

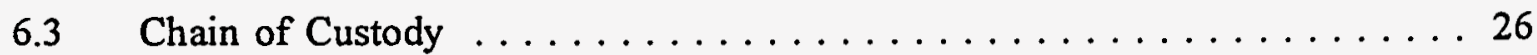

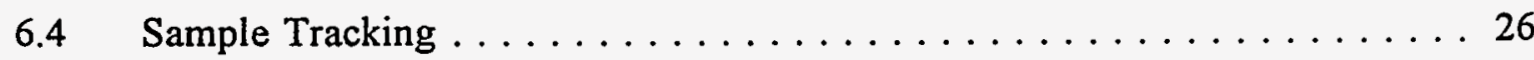

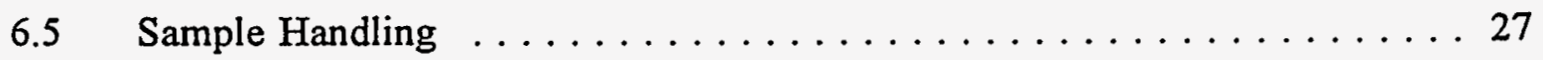

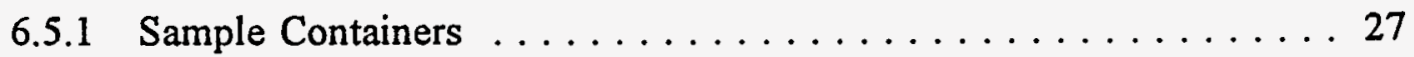

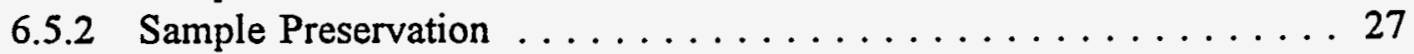

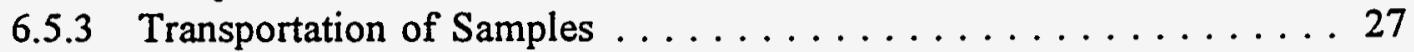

6.5.4 Field Monitoring for Organic Vapors $\ldots \ldots \ldots \ldots \ldots \ldots \ldots$

7. ANALYTICAL PROCEDURE . . . . . . . . . . . . . . . . 29

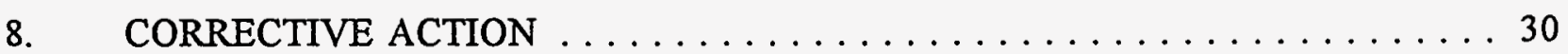

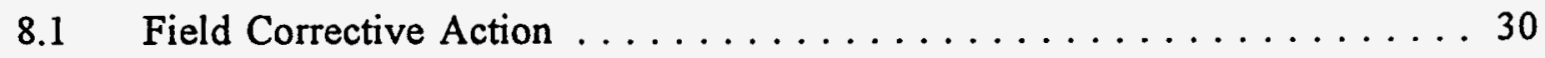

8.2 Laboratory Corrective Action $\ldots \ldots \ldots \ldots \ldots \ldots \ldots \ldots \ldots \ldots \ldots \ldots \ldots$

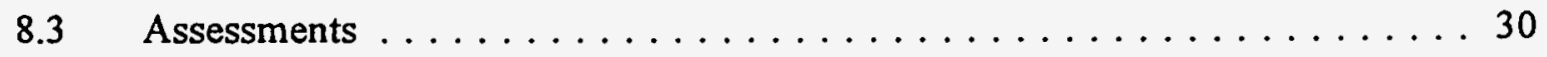

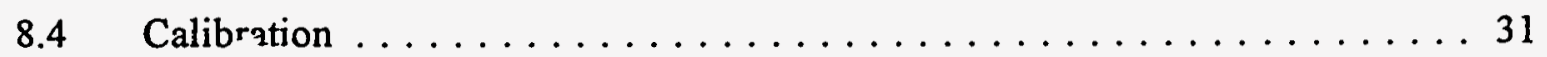

8.4.1 Calibration Records $\ldots \ldots \ldots \ldots \ldots \ldots \ldots \ldots \ldots \ldots \ldots \ldots \ldots$

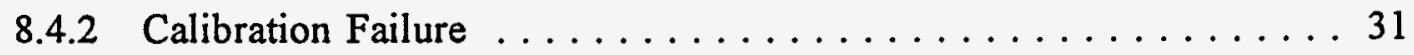

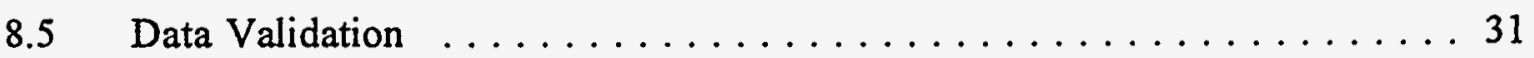

9. WASTE MINIMIZATION $\ldots \ldots \ldots \ldots \ldots \ldots \ldots \ldots \ldots \ldots \ldots \ldots \ldots$

10. HEALTH AND SAFETY CONSIDERATIONS $\ldots \ldots \ldots \ldots \ldots \ldots \ldots$ 
$10.1 \quad$ Radioactive Spill Control $\ldots \ldots \ldots \ldots \ldots \ldots \ldots \ldots \ldots \ldots \ldots$

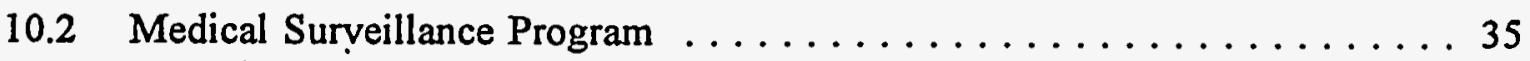

10.3 Emergency Reference List $\ldots \ldots \ldots \ldots \ldots \ldots \ldots \ldots \ldots$

11. HAZARD EVALUATION $\ldots \ldots \ldots \ldots \ldots \ldots \ldots \ldots \ldots \ldots \ldots \ldots \ldots \ldots \ldots$

11.1 Chemical Hazards $\ldots \ldots \ldots \ldots \ldots \ldots \ldots \ldots \ldots \ldots \ldots \ldots \ldots$

11.1.1 Routes of Chemical Exposure $\ldots \ldots \ldots \ldots \ldots \ldots \ldots \ldots \ldots$

11.1.2 Indicators of Chemical Exposure .............. 38

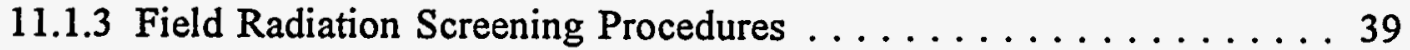

11.2 Physical Hazards . . . . . . . . . . . . . . . . . . . 39

11.2.1 Ionizing Radiation $\ldots \ldots \ldots \ldots \ldots \ldots \ldots \ldots \ldots \ldots \ldots$

11.2.2 Industrial Safety Hazards . . . . . . . . . . . . . 40

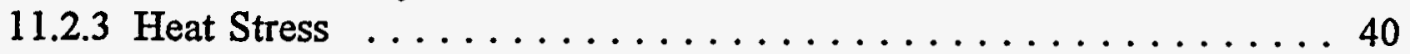

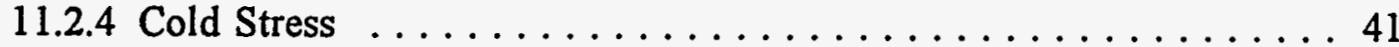

11.2.5 Decontamination ....................... 42

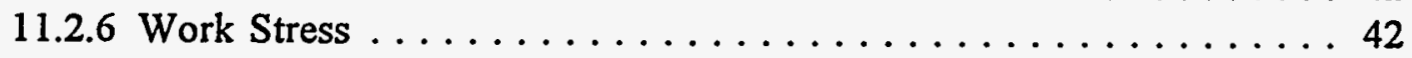

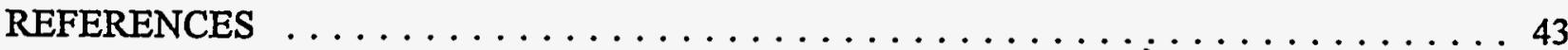




\section{EQUATIONS}

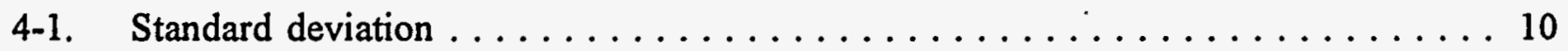

4-2. Percent relative standard deviation (\% RSD) $\ldots \ldots \ldots \ldots \ldots \ldots \ldots \ldots$

4-3. Field Accuracy $(\%$ Recovery) $\ldots \ldots \ldots \ldots \ldots \ldots \ldots \ldots \ldots \ldots \ldots \ldots \ldots$

4-4. Laboratory accuracy $(\%$ Recovery) $\ldots \ldots \ldots \ldots \ldots \ldots \ldots \ldots \ldots$

\section{FIGURES}

3-1. OP-FTIR results for carbon tetrachloride in ASB- $\Pi$ facility $\ldots \ldots \ldots \ldots \ldots \ldots 5$

4-1. Open Path-FTIR schematic monitoring between drums $\ldots \ldots \ldots \ldots \ldots \ldots 14$

4-2. Plan view of a WMF Type II Module $\ldots \ldots \ldots \ldots \ldots \ldots \ldots \ldots \ldots \ldots$

4-3. Plan view of the WMF Type I Module $\ldots \ldots \ldots \ldots \ldots \ldots \ldots \ldots$

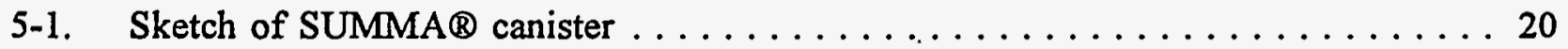

\section{TABLES}

3-1. Range of VOCs concentrations detected in the $\mathrm{C} \& \mathrm{~S}$ building $\ldots \ldots \ldots \ldots 5$

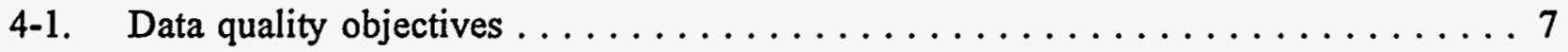

4-2. Type I and II Waste Storage Modules and tentative operation schedule $\ldots \ldots \ldots 12$

4-3. OP-FTIR Monitoring and SUMMA@ Sampling schedule for the Type II Modules . 13 


\section{ACRONYMS}

ASB-II Air Support Weather Shield No. 2 Building

C \& S Certified and Segregated Building

CFA Central Facilities Area

CFR Code of Federal Regulations

COC Chain of custody

DOE Department of Energy

DOT Department of Transportation

EPA Environmental Protection Agency

ERD - Environmental Restoration Department

ETU Environmental Technology Unit

FTL Field team leader

FSOP Field standard operating procedure

GC/MS Gas chromatography/mass spectrometry

$\mathrm{IH} \quad$ Industrial hygienist

INEL Idaho National Engineering Laboratory

MDL $\quad$ Method detection limit

MS/MSD Matrix spike/matrix spike duplicate

OMP Occupational Medical Program

OP-FTIR Open-path Fourier transform infrared spectroscopy

OSHA Occupational Safety and Health Administration

OVM Organic vapor monitors

PPE Personal protective equipment 
QA Quality assurance

QAPjP Quality assurance project plan

QC Quality control

RCT Radiological control technician

RCRA Resource Conservation Recovery Act

RSD Relative standard deviation

RWMC Radioactive Waste Management Complex

RWP Radiological work permit

SOW Statement of work

SwRI Southwest Research Institute

SWEPP Stored Waste Examination Pilot Plant

TAP Toxic Air Pollutant

TRU Transuranic

TSA Transuranic Storage Area

TSDF Treatment, Storage, and Disposal Facility

VOCs Volatile organic compounds

WCC Warning Communication Center

WMF Waste Management Facility

WSF Waste Storage Facility 


\section{Monitoring Plan for Organic Air Emissions at the Radioactive Waste Management Complex Waste Storage Facilities}

\section{PROJECT DESCRIPTION}

The purpose of this monitoring plan is to systematically identify and routinely monitor (qualitatively and quantitatively) volatile organic compounds (VOCs) emitted from the Waste Storage Facilities (WSFs) located within the Transuranic Storage Area (TSA) at the Idaho National Engineering Laboratory (INEL) Radioactive Waste Management Complex (RWMC). VOCs included (but not limited to) in this monitoring effort will include carbon tetrachloride, chloroform, 1,1,1-trichloroethane, dichloromethane, Freon 113, and trichloroethylene. The WSFs encompass both the Type I and Type II Waste Storage Modules. The outlined monitoring will implement a dual method approach using Open-Path Fourier Transform Infrared Spectroscopy (OP-FTIR) in situ, real time monitoring in conjunction with ancillary SUMMA@ canister sampling, following the U. S. Environmental Protection Agency (EPA) analytical method TO-14. The SUMMA® canister samples will be analyzed using gas chromatograph/mass spectrometry (GC/MS) analysis. A portable gas chromatograph may be used at the discretion of the field team to provide field screening and spacial information.

Construction of seven Type II Waste Storage Modules and one Type I Waste Storage Module is in progress. The Type II Modules, Waste Management Facility (WMF)-628 and WMF-629, are anticipated to be completed this spring (1994) and will be the first two active facilities requiring monitoring. The remaining Waste Storage Modules are currently under construction. Once construction of each module is completed, it will be included in the routine monitoring plan. The monitoring plan and collected data will be evaluated to determine monitoring capabilities, needs, and plan effectiveness as each module is brought on line. The monitoring plan will be revised as necessary. The collected data will also be used assess the criteria for monitoring other planned TSA facilities.

The data collected from routine monitoring will be used so determine a basis for future evaluation of the concentrations of VOCs emitting from wastes stored at the TSA. These monitoring activities are driven by the Phase II Proposed Rule on Organic Air Emissions from Resource Conservation Recovery Act (RCRA) Treatment Storage Disposal Facility (TSDF) which use containers, tanks and surface impoundments during hazardous waste management operations (56 Federal Register 33489 - 33580). The objective of the Phase II proposed rule is to reduce organic air emissions from specific RCRA-regulated units. The WSFs are included in the RCRAregulated envelop. 
Monitoring data will also provide information to assess personnel exposure to hazardous wastes and toxic materials with regard to Occupational Safety and Health Administration (OSHA) and assist in addressing compliance with the State of Idaho air emissions regulations. OSHA has established personal chemical concentration exposure limits in 29 Code of Federal Regulations (CFR) 1910.1000. OSHA also enacted 20 CFR 1910.120 to protect the health and safety of personnel at hazardous waste site operations and TSDFs. The State of Idaho Department of Health and Welfare (IDHW) has recently promulgated (April 1994, effective May 1, 1994) revised regulations, part of which are intended to control toxic air pollutant (TAP) emissions in Idaho. Accurate organic air emissions monitoring data will be helpful in addressing compliance with the TAP increments.

In addition to describing monitoring activity details, this monitoring plan will function as a Quality Assurance Project Plan (QAPjP). The QAPjP serves as a controlling mechanism during monitoring, sampling, and analysis to ensure that all data collected are valid, reliable, and defensible. This document outlines the organization, objectives, and quality assurance/quality control (QA/QC) activities needed to achieve the desired data quality objectives. Health and safety considerations for the monitoring activities are also addressed in this monitoring plan. 


\section{PROJECT ORGANIZATION AND RESPONSIBILITIES}

The following is a list of key project personnel and their corresponding responsibilities:

T. O. Bodily RWMC Industrial Hygiene

J. R. Bishoff

T. D. Cline

K. J. Galloway

M. R. Hankins

K. J. Izbicki

J. M. Jackson

J. G. Jolley

G. A. Schroder

M. J. Sherick
RWMC/SWEPP Operations

Unit Manager

RWMC Shift Supervisor

Monitoring Field Team Leader

Assistant Monitoring Field Team Leader

Sample Management Office/

Analytical Services

ES\&Q Project Manager

Monitoring Field Technical Leader

RWMC Quality Assurance

RWMC Project Manager
$526-7964$

$526-2766$

$526-2767$

$526-0902$

$526-8321$

$526-1474$

$526-7929$

$526-8036$

$526-5651$

$526-4212$

All personnel performing the field monitoring and ancillary sampling activities must have completed the OSHA 40-hour hazardous waste operations training, radiation worker training, RWMC Orientation Access Training, respirator training, and on-the-job training requirements. All safety training is documented by the EG\&G Safety Training System and is also available in individual training files. 


\section{EXISTING DATA}

\subsection{Existing Site Information}

The TSA is a transuranic (TRU) waste storage area located in the southeastern section of the RWMC. The TSA facilities at the RWMC are used to store drums of radioactive and mixed (radioactive and hazardous) wastes. The Waste Storage Modules are being constructed at the TSA to provide additional storage for radioactive wastes before shipment to other Department of Energy (DOE) facilities for final disposal or to an appropriate on-site (INEL) or off-site waste treatment facility.

Many of the drums in the TSA facilities are vented to eliminate radiolitically generated hydrogen gas build up. The drums are fitted with a carbon composite filter that allows the hydrogen gas to vent while preventing the radionuclides from escaping out of the drum. The filters, however, do not block, adsorb, or trap escaping VOCs. Monitoring of VOC concentrations is being implemented at the WSFs to determine the presence and concentration of ambient air organic emissions, to further assess the potential for personnel exposure, and to determine potential monitoring needs for future planned TSA facilities.

\subsection{Analysis of Existing Data}

During the summer of 1991, the OP-FTIR was demonstrated (by an OP-FTIR vendor) in the Certified and Segregated (C\&S) Building of the RWMC. The OP-FTIR was used to measure carbon tetrachloride, dichloromethane, 1,1,1-trichloroethane, 1,1,2-trichlorotrifluoroethane (Freon 113), propane, and ammonia within the C\&S facility. Table 3-1 lists the range of VOCs detected

during this demonstration. It is important to note that these data are not QA/QC verified and were for demonstration purposes only.

During the latter part of Fiscal Year (FY-92), a task was initiated to characterize the organic air emissions from the Air Support Weather Shield II (ASB-II) (WMF 711) at the TSA. The purpose of this task was to identify and quantify the VOCs present in the ambient air in the faci:y and to estimate the organic air emissions. The C\&S and ASB-II buildings serve similar functions as the Type I and II Waste Storage Modules, to provide storage for radioactive and mixed wastes. The VOCs were identified and quantified using the OP-FTIR. Figure 3-1 shows the OP-FTIR results for carbon tetrachloride analysis at five minute intervals, 24 hours a day for $2 \frac{1}{2}$ days at the ASB- $\Pi$ facility. OP-FTIR data analysis indicates that concentrations in the ASBII vary significantly with time. 
Table 3-1. Range of VOC concentrations detected in the C\&S building using OP-FTIR.

\begin{tabular}{|l|c|}
\hline \multicolumn{1}{|c|}{ Compound } & Concentration (ppb) \\
\hline \hline Ammonia & $80-100$ \\
\hline Carbon tetrachloride & $210-450$ \\
\hline Dichloromethane & MDL -760 \\
\hline Propane & $1020-1200$ \\
\hline $1,1,2-$ Trichlorotrifluoroethane & $80-150$ \\
\hline $1,1,1$-Trichloroethane & $150-350$ \\
\hline \hline
\end{tabular}

MDL - method detection limit

In all likelihood, this variation is due to temperature and to a lesser degree pressure changes (e.g., as temperature increases and pressure decreases, concentration increases).

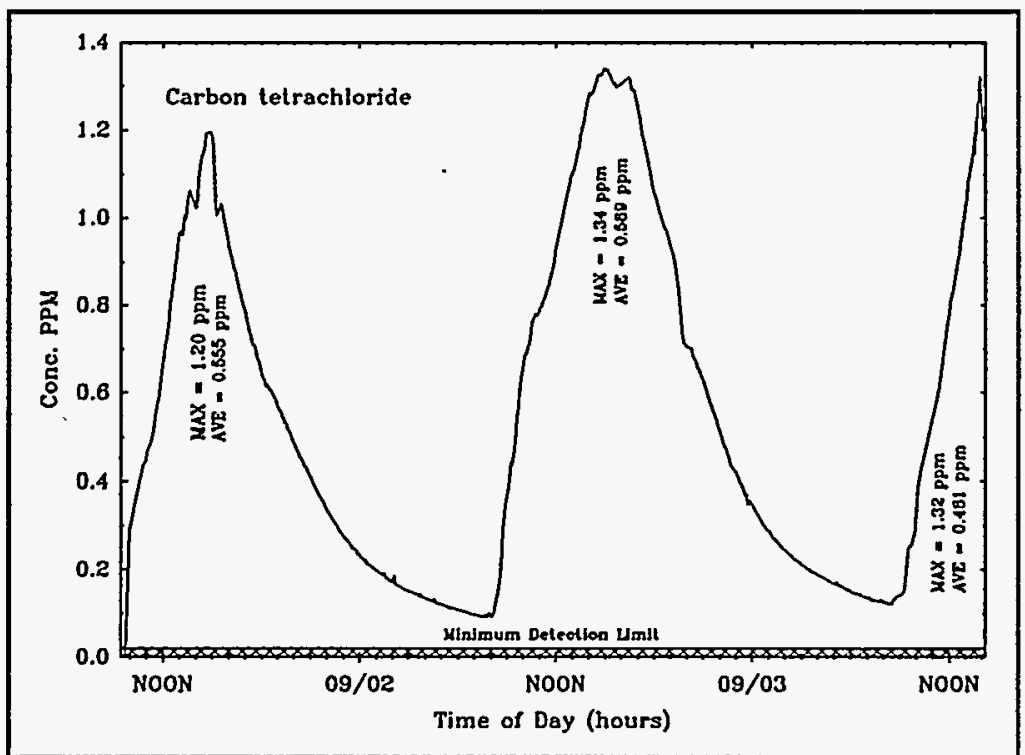

Figure 3-1. OP-FTIR results for carbon tetrachloride in ASB- $\Pi$ facility. Continuous in situ, real time analysis at five minute intervals for $2 \frac{1}{2}$ days. 


\section{QUALITY ASSURANCE OBJECTIVES AND MONITORING STRATEGY}

\subsection{Objectives}

Previous analysis at the TSA indicated the presence of VOCs (Table 3-1). The objectives of the proposed monitoring, ancillary sampling, and analysis for the Type $\mathrm{I}$ and $\Pi$ Modules are to:

- provide identification and quantification information in support of the air emissions at the Type I and II Modules for the INEL site-wide Clean Air Act (CAA) Title V Permit to Operate (PTO),

- provide confirmatory monitoring data to ensure compliance with the OSHA worker safety standards,

- assist in determining the level of safety provided to visitors touring the TSA,

- provide information to support the consent order negotiations preparation activities addressing the RCRA Subpart CC proposed rule,

- determine if the need exists for the provision of VOC emission control equipment for some or all of the facilities currently located at or scheduled to be constructed at the TSA,

\subsection{Data Quality Objectives}

The data quality objectives (DQOs) for the organic air emission monitoring and ancillary sampling are to identify the VOCs present and determine concentration levels as a function of meteorological conditions. The development of this monitoring plan is driven by regulatory compliance to the Resource Conservation and Recovery Act, State of Idaho Toxic Air Pollutant increments, and the Occupational Safety and Health Administration. The data quality objectives listed in Table 4-1 are designed to ensure that the uara collected are of sufficient quality to meet the project requirements. 


\subsubsection{Analytical Levels}

\subsubsection{OP-FTIR}

All OP-FTIR monitoring will be performed to Quality Level 3 in accordance with the $E G \& G$ Idaho, Inc. Quality Manual. These data will be used for decisions that require a high level of confidence. A draft EPA Field Standard Operating Procedure (FSOP) will be used until an approved EPA FSOP is available. (Reference Draft EPA FSOP.)

Table 4-1. Data quality objectives.

\begin{tabular}{|c|c|c|c|c|}
\hline Analysis & Method(s) & $\begin{array}{l}\text { Detection } \\
\text { limit }\end{array}$ & $\begin{array}{l}\text { Analytical } \\
\text { level }\end{array}$ & $\begin{array}{l}\text { Prioritized } \\
\text { data use }\end{array}$ \\
\hline VOCs & $\mathrm{TO}-14^{\mathrm{a}}$ & $\begin{array}{l}\text { Method } \\
\text { detection limit }\end{array}$ & IV & $\begin{array}{l}\text { Identify VOCs } \\
\text { and associated } \\
\text { concentration }\end{array}$ \\
\hline VOCs & OP-FTIR & $\begin{array}{l}\text { Method } \\
\text { detection limit }\end{array}$ & $3^{d}$ & $\begin{array}{l}\text { Identify VOCs } \\
\text { and associated } \\
\text { concentration }\end{array}$ \\
\hline VOCs & Portable GC & $\begin{array}{l}\text { Method } \\
\text { detection limit }\end{array}$ & $\Pi$ & $\begin{array}{l}\text { Field Screen, } \\
\text { Identify VOCs } \\
\text { and associated } \\
\text { concentration }\end{array}$ \\
\hline
\end{tabular}

a. U.S EPA "Compendium Method TO-14, The Determination of Volatile Organic Compounds in Ambient Air Using SUMMA® Passivated Canister Sampling and Gas Chromatographic Analyses."

b. The method detection limit for the specified analysis will be used

c. Draft U.S EPA "Field Standard Operating Procedure for the Use of Open-Path FTIR Spectroscopy at Hazardous Waste Sites" (March 1992)

d. OP-FTIR monitoring will be performed to Quality Level 3, EG\&G Idaho Quality Manual. 


\subsubsection{SUMMA@ Canisters}

VOC analyses performed by an offsite laboratory will be analyzed to Analytical Level IV. Analytical Level IV is defined as analyses performed by an approved laboratory procedure. These data will be used for decisions that require a high level of confidence. Approved EPA methods will be used.

Generally, the analyses performed using Level IV techniques are designed to provide confirmed identification and quantification of organic and inorganic compounds in water, sediment, soil, and air samples. Level IV data provides information for risk assessments, for evaluations of alternatives, and for engineering studies.

\subsubsection{Portable Gas Chromatograph}

The VOC analyses performed with a portable gas chromatograph will be analyzed to Analytical Level II. Analytical Level II techniques are designed to provide field screening information.

\subsubsection{Data Completeness, Representativeness, and Comparability}

The quality assurance (QA) objective for measurement data is to ensure that air characterization data are of known and acceptable quality. Data from monitoring activities and ancillary laboratory analysis of air samples will be used to define a baseline history.

\subsubsection{Representativeness}

Representativeness expresses the degree to which monitoring and sample data accurately and precisely represent a characteristic of a population, parameter variations at a sample point, or an environmental condition. Representativeness is a qualitative parameter that is a function of the proper design and strategy of the monitoring and sampling program. The representativeness criterion is best satisfied by making certain that the monitoring and sampling methods are selected and documented properly, and that a sufficient number of areas are monitored and samples collected. 


\subsubsection{Completeness}

Completeness is the amount of valid data obtained compared to the amount that was expected under normal conditions. Completeness can be expressed as the percentage of valid measurements. To achieve adequate completeness, a sufficient amount of valid data must be generated. The completeness goal for this project is $85 \%$. Completeness for this project will be assessed by comparing the number of planned monitoring and sampling events to the number of actual events conducted (including validation). If the number of actual events conducted versus the planned events do not meet the completeness goal, then there may be data gaps.

\subsubsection{Precision}

Precision is a measure of mutual agreement among individual measurements of the same property, under identical conditions. OP-FTIR precision will be assessed using a surrogate compound which adsorbs within the infrared regions where compounds of monitoring interest absorb. This will yield precision information on the data as well as the analysis method.

Sampling precision will be assessed by means of laboratory duplicate/field replicate sample analysis. At the laboratory, the objective for precision is to equal or exceed the precision demonstrated for similar samples, and shall be within the established control limits for EPA methods (Compendium of Methods for the Determination of Toxic Organic Compounds in Ambient Air, June 1988).

\subsubsection{Field Precision}

Field sampling precision will be calculated using results of replicate samples as both the standard deviation and the percent relative standard deviation (\% RSD). The standard deviation, s, is calculated as follows: 


$$
s=\sqrt{\frac{\sum_{i=1}^{n}\left(x_{i}-\bar{x}\right)^{2}}{n-1}}
$$

The \% RSD is then

$$
\% \mathrm{RSD}=\frac{\mathrm{s}}{\overline{\mathrm{x}}} \times 100 \%
$$

The standard deviation and \% RSD are calculated for every contaminant measured.

\subsubsection{Laboratory Precision}

Sampling precision of the chemical laboratory data will be measured through the use of the matrix spike/matrix spike duplicate (MS/MSD) samples and will be calculated as the \% RSD.

\subsubsection{Accuracy}

Accuracy means the nearness of a result, or the mean of a set of results, to the true value. Accuracy is assessed by means of reference samples and percent recoveries.

\subsubsection{Field Accuracy}

Determining whether a monitoring or sampling event will yield results that accurately reflect the true concentration of a compound in the air, soil, sediment, or groundwater cannot be quantitatively assessed. However, the monitoring and sar : " $\mathrm{g}$ methods described in this plan have been chosen to be representative of the media being monitored and sampled.

OP-FTIR measurement accuracy will be assessed by introducing an appropriate concentration of one or more representative compounds (NIST traceable gas standards) of monitoring interest into an internal QA gas cell. Accuracy calculations are as follows: 


$$
\% \text { Recovery }=\frac{C_{M Q}-C_{M}}{C_{A}} \times 100 \%
$$

where

$\mathrm{C}_{\mathrm{MQ}}$ is the measured compound concentration with the calibration gas standard in the QA cell

$\mathrm{C}_{\mathrm{M}}$ is the measured compound concentration

$\mathrm{C}_{\mathrm{A}}$ is the calibration gas standard concentration

\subsubsection{Laboratory Accuracy}

The quality assurance project plans and standard operating procedures (SOPs) of the analytical laboratory will describe procedures to evaluate accuracy. Evaluation of accuracy will be used to help determine if the laboratory is in protocol specification limits and to assign uncertainty values to the data.

Sampling accuracy of the chemical laboratory data will be determined from the \% Recovery of MS/MSD analysis and any. certified standards that the laboratory analyzes as part of its ongoing $\mathrm{QA} /$ quality control (QC) program. The \% Recovery is calculated as follows:

$$
\% \text { Recovery }=\frac{\text { SSR-SR }}{\text { SA }} \times 100 \%
$$

where

$$
\begin{aligned}
& \text { SSR }=\text { spiked sample result } \\
& \text { SR }=\text { sample result } \\
& \mathrm{SA}=\text { spike added. }
\end{aligned}
$$

The laboratory is also required to run a sufficient number and type of blanks to detect laboratory contamination. 


\subsection{Monitoring Strategy and Design}

Construction of seven Type II Waste Storage Modules and one Type I Waste Storage Module is in progress. The Type II Modules, Waste Management Facility (WMF)-628 and WMF-629, are anticipated to be completed this spring (1994) and will be the first two active facilities requiring monitoring. Table 4-2 lists the Waste Storage Modules and a tentative operational readiness schedule.

Routine monitoring will be provided for each of the facilities as they become operational. VOCs included (but not limited to) in this monitoring effort will include carbon tetrachloride, chloroform, 1,1,1-trichloroethane, dichloromethane, Freon 113, and trichloroethylene. The monitoring plan and data will be evaluated on a periodic basis and prior to each facility being added to the monitoring schedule to assess available monitoring capabilities, determine monitoring needs, and to revise the monitoring plan as necessary.

Table 4-2. Type I and II Waste Storage Modules and Tentative Operation Schedule.

\begin{tabular}{||c|c|c||}
\hline Facility & Building No. & Release to Operate \\
\hline \hline Type II Module & WMF-628 & Fall 1994 \\
\hline Type II Module & WMF-629 & Fall 1994 \\
\hline Type II Module & WMF-630 & Spring 1995 \\
\hline Type II Module & WMF-631 & Winter 1995 \\
\hline Type II Module & WMF-632 & Winter 1995 \\
\hline Type II Module & WMF-633 & Winter 1995 \\
\hline Type II Module & WMF-634 & Winter 1995 \\
\hline Type 1 Module & WMF-635 & Spring 1995 \\
\hline \hline
\end{tabular}




\subsubsection{OP-FTIR Monitoring}

\subsubsection{OP-FTIR.Monitoring Frequency}

The OP-FTIR monitoring will rotate between facilities that contain waste containers on a routine basis. For the first six months of operational monitoring, the rotation frequency will be weekly between WMF-628 and WMF-629. Table 4-3 presents the sampling schedule for the first six weeks of operational monitoring.

Table 4-3. OP-FTIR monitoring and SUMMA® canister sampling schedule for the Type II Modules.

\begin{tabular}{|c|c|}
\hline WEEK & FACIITY \\
\hline \hline 1 & WMF-628 Type II Module \\
\hline 2 & WMF-629 Type II Module \\
\hline 3 & WMF-628 Type II Module \\
\hline 4 & WMF-629 Type II Module \\
\hline 5 & WMF-628 Type II Module \\
\hline 6 & WMF-629 Type II Module \\
\hline
\end{tabular}

For example, week 1 the OP-FTIR will monitor WMF-628, week 2 WMF-629, week 3 WMF628 , etc. This is assuming waste containers will be moved into WMF-628 and WMF-629 simultaneously. After six months, the OP-FTIR data will be evaluated. The frequency of rotation may be adjusted.

\subsubsection{OP-FTIR Monitoring Location}

The Type II Modules are of similar construction and layout. The OP-FTIR will be setup to monitor the areas between waste storage drums. The OP-FTIR may be moved on occasion within a facility to determine concentration levels in different areas and to avoid interference with other WMF activities. The OP-FTIR will be set up to primarily monitor at or near the breathing zone approximately ( 4 to $6 \mathrm{ft}$ above floor surface) in each area. Section 5 discusses the procedures 
for OP-FTIR Operation. Figure 4-1 provides a schematic of the OP-FTIR setup between drums.

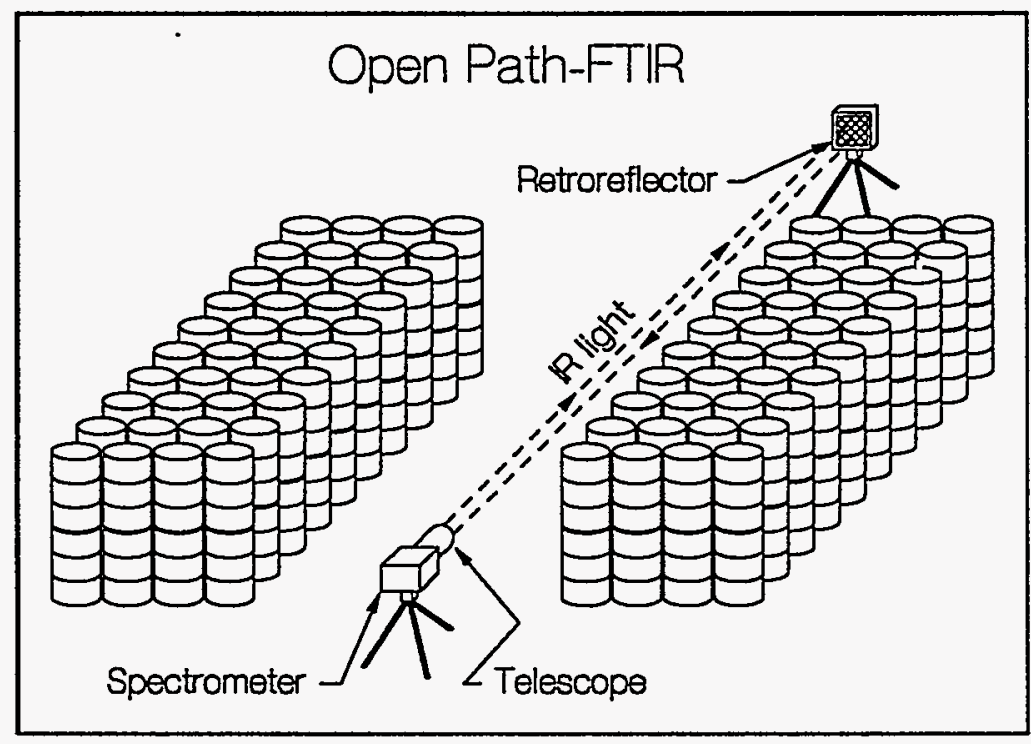

Figure 4-1. Open Path-FTIR schematic. Infrared light shining through the air from the spectrometer is reflected back by the retroreflector mirror. Air is undisturbed during analysis.

Figure 4-2 shows the general conceptual layout of the Type II Modules and Figure 4-3 diagrams the Type I Module.

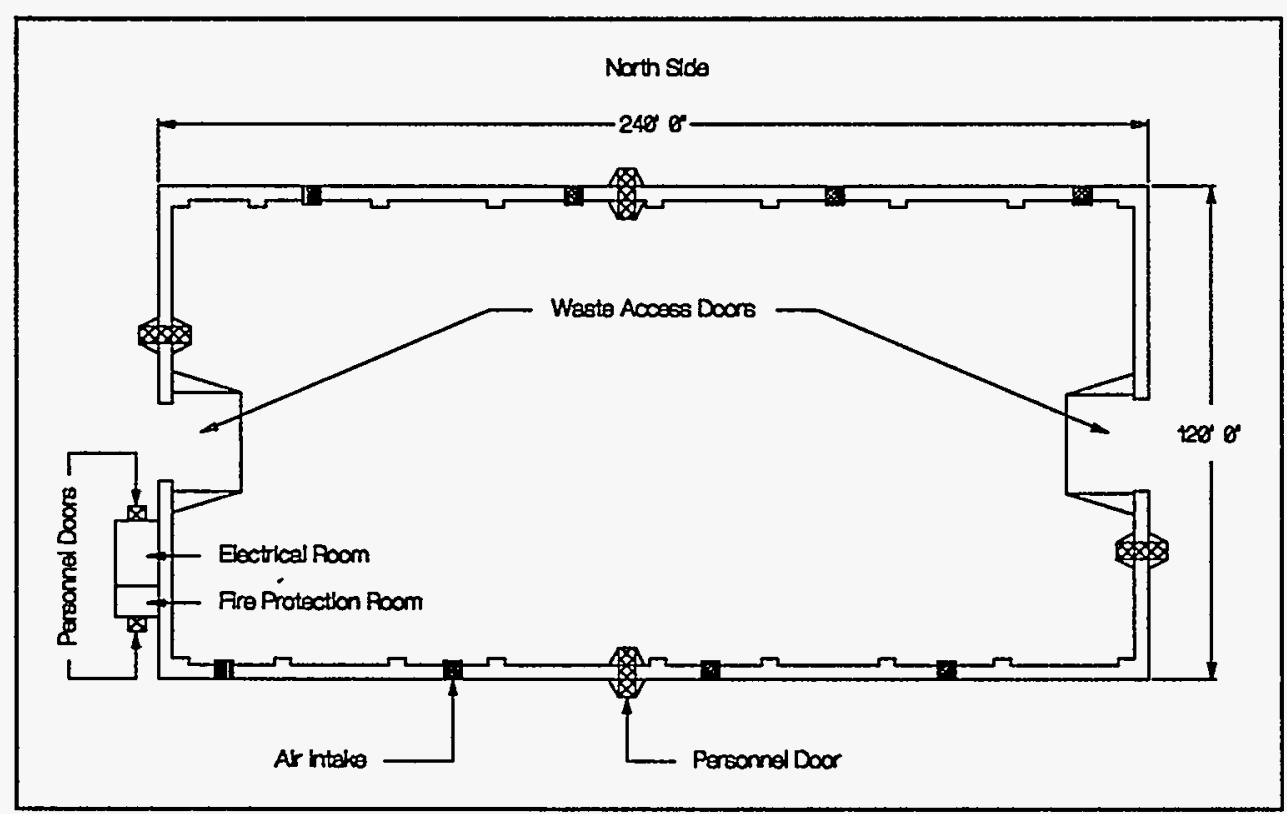

Figure 4-2. Plan View of a WMF Type II Module. 


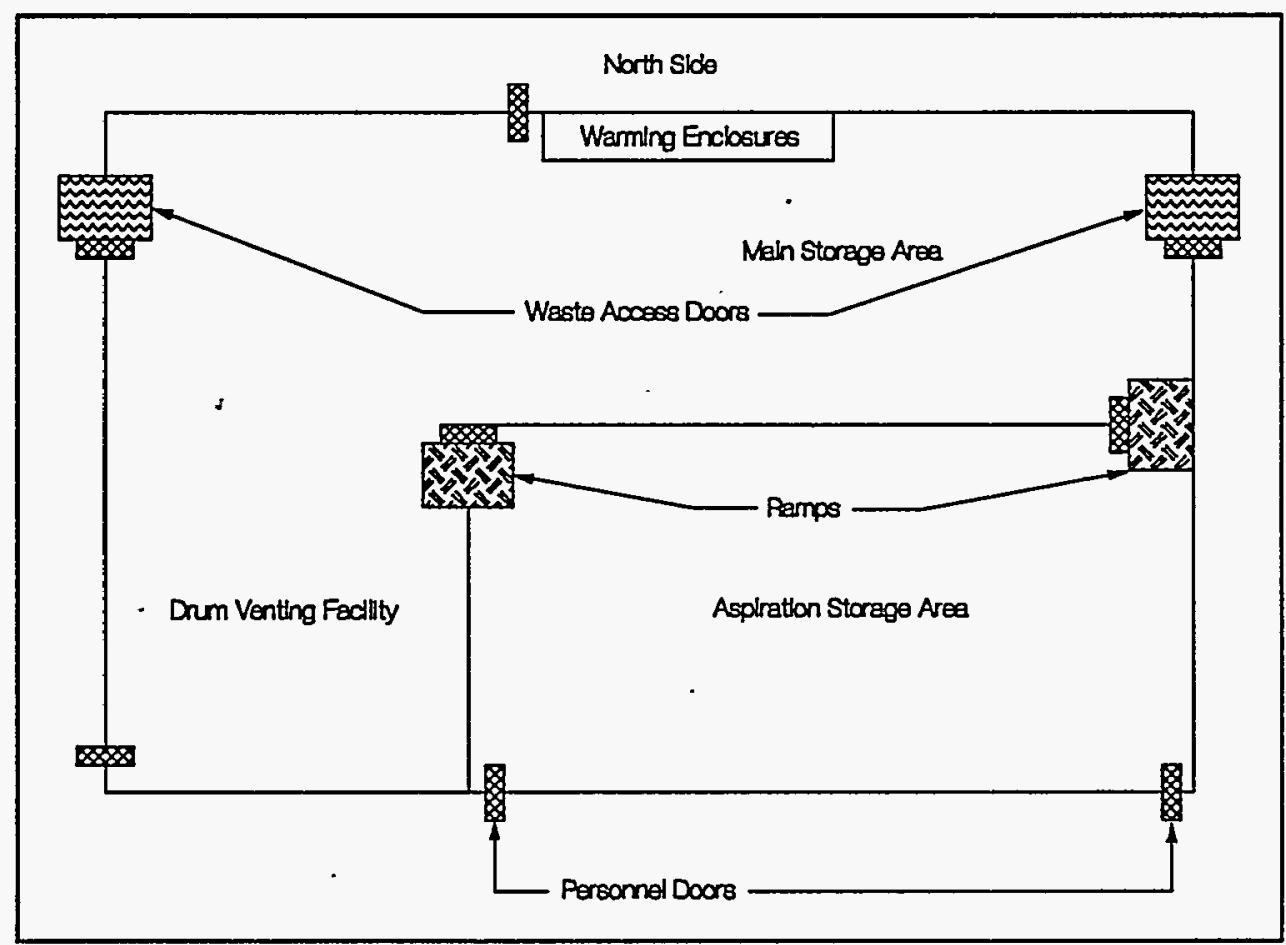

Figure 4-3. Plan View of a WMF Type I Module.

\subsubsection{SUMMA® Canister Sampling}

\subsubsection{SUMMA@ Sampling Frequency}

For the first six weeks of operational monitoring, SUMMA@ canister sampling will be coordinated with the OP-FTIR monitoring. The SUMMA@ canister sampling will be used as verification information to supplement the OP-FTIR data. After the initial six weeks, routine SUMMA® sampling will cease, however, OP-FTIR monitoring will continue on a routine schedule. Periodically, SUMMA® samples will be collected to support OP-FTIR data. Monitoring and sampling locations may vary for each sampling event. This is a function of activities being conducted at the facilities. Monitoring and sampling will not interfere with routine operations at the WSFs.

\subsubsection{SUMMA® Sampling Locations}

The SUMMA@ canister sampling will be conducted in the area adjacent to the OP-FTIR system, preferably in the breathing zone ( 4 to $6 \mathrm{ft}$ above ground surface). Five SUMMA® canisters are available per week for the initial six week operational monitoring. One sample per sampling 
event (per week) will be a blank. A standard and a duplicate sample will be sent every two weeks. The other three to four available SUMMA@ canisters per weekly sampling event will be field samples.

In addition, periodic sampling of the WSFs ventilation exhaust air effluent will be performed. These samples will assist in assessing the facility atmospheric emissions for compliance with the State of Idaho air emission regulations.

The field samples will consist of SUMMA® walk samples and stationary SUMMA@ samples. The SUMMA@ walk samples are obtained by transporting a SUMMA@ canister adjacent to the beam of the OP-FTIR. This provides path-averaged VOC concentration measurements for both the OP-FTIR and SUMMA@ sampling methods simultaneously. The stationary samples will be positioned at locations usually adjacent to the OP-FTIR beam and allowed to collect a sample for set periods of time.

\subsubsection{Portable Gas Chromatograph Sampling}

A portable gas chromatograph may be used at the discretion of the field team to provide field screening information during OP-FTIR monitoring and SUMMA@ Canister Sampling.

\subsubsection{Quality Assurance/Quality Control Samples}

A trip blank will be sent with the batch of samples shipped weekly to the laboratory. A blind field standard and a duplicate sample will be sent periodically to check the performance of the laboratory. 


\section{MONITORING AND SAMPLING PROCEDURES}

\subsection{Monitoring and Sampling Preparation}

The following preparation activities will be performed prior to initiation of actual sample collection and monitoring:

1. Notify all appropriate parties [shift supervisor, area radiological control technicians (RCTs), area industrial hygienist (IH), etc.] prior to arrival at the monitoring and sampling sites. A radiological work permit (RWP) may be required prior to initiation of activities.

2. Prepare a clean, unobstructed area for equipment layout.

3. As required by the FTL, IH, or radiological work permit, monitoring of the breathing zone for potentially hazardous/toxic vapors and radioactivity will be performed. It will be the responsibility of the onsite $\mathrm{IH}$ and RCT to provide guidance and appropriate equipment.

4. The $\mathrm{RCT}$ and $\mathrm{IH}$ will reassess personal protection requirements and prescribe any other required precautions prior to any sampling or measuring of air emissions. Sampling activities will be suspended at the discretion of the $\mathrm{IH}$ and/or RCT. Review of the situation by the FTL, RWMC project manager, IH, RCT, and other appropriate facility personnel is required prior to resuming activities.

\subsection{OP-FTIR Monitoring}

\subsubsection{OP-FTIR Operation Procedures}

OP-FTIR monitoring will be conducted in accordance as applicable with Draft U.S EPA "Field Standard Operating Procedure for the Use of Open-Path FTIR Spectroscopy at Hazardous Vi aste Sites" (March 1992). In addition, the "FT-IR Open-Path Monitoring Guidance Document" (March 1993) has been referenced to provide additional OP-FTIR operation guidance. See Figure 4-1 for OP-FTIR schematic.

The spectrometer will be placed facing and in line with the retroreflector at select distances apart and will generally monitor areas at or near floor and breathing zone heights. Procedures for 
monitoring using the OP-FTIR are as follows:

1. Position spectrometer and retroreflector to collect an $\mathrm{I}_{\mathrm{o}}$ reference spectra. Record start time of cryocooler, maximum detector counts, location, time of collection, temperature (inside TSA facility) and barometric pressure (inside TSA facility) in the OP-FTIR logbook.

2. Introduce surrogate compound (calibration gas) into the QA cell, perform system verification, and record results in the OP-FTIR logbook.

3. Position retroreflector to collect the area spectra and continue system verification. Record location, path length from the retroreflector to the spectrometer and time of collection start in the OP-FTIR logbook.

4. Purge QA cell with dry $\mathrm{N}_{2}$ (from high purity gas cylinder or liquid nitrogen boil off) and confirm that surrogate compound concentration in the cell is below the MDL.

5. Start continuous monitoring and record the start time of collection in the OP-FTIR logbook.

6. Upon termination of continuous monitoring, record maximum detector counts, stop time of cryocooler, time of collection termination, temperature (inside TSA facility) and barometric pressure (inside TSA facility) in the OP-FTIR logbook.

7. Down load and double backup all relevant data files. Store one backup set at the WCB.

The FTL (or designated alternate) will check the operation of the monitoring system at least once during each monitoring event. During this check, the FTL will ensure that the OP-FTIR is operational. Any adjustments made to the OP-FTIR will be noted in the OP-FTIR logbook. In addition, the FTL will conduct a routine safety inspection of the equipment and general area to ensure that safe conditions are maintained. The FTL will note any operational events witnessed or made aware of (e.g., changes in ventilation of building, painting, drum venting, etc.). 


\subsubsection{OP-FTIR Monitoring Equipment List}

\section{Monitoring device:}

OP-FTIR

\section{Other equipment:}

Extension cords and power strip

Plastic bags

Black indelible ink pens

Nitrogen purge gas supply

Surrogate compounds

Calibration standards

Tygon tubing

OP-FTIR logbook

Gas cylinder regulators

Tools for assembly, modification and maintenance

Calibrated thermometer and barometer

Duct tape

Measuring tapes

\subsection{SUMMA® Sampling, Method TO-14}

\subsubsection{Sample Collection}

Air samples will be collected in 6-liter SUMMA® passivated canisters and analyzed for VOCs using Gas Chromatography/Mass Spectrometry (GC/MS) in accordance with U.S. EPA Compendium of Methods for the Determination of Toxic Organics in Ambient Air, Method TO14.

A flow control device allows for a constant flow into the canister over the desired sample period. The flow rate and sample period will be determined by the FTL. The flow control devices are a gross indicator of the pressure inside the canister. See Figure 5-1 for a diagram of a SUMMA@ canister. Procedures for collecting the air samples using the SUMMA® canisters are as follows:

1. Record SUMMA® canister identification numbers, sample ID number, location 
in TSA facility, name of TSA facility, and the gauge pressure in the sample logbook. See figure 5-1 for SUMMA® canister sketch.

2. Measure the temperature and barometric pressure from inside the TSA facilities and record in the sample logbook just prior to sampling.

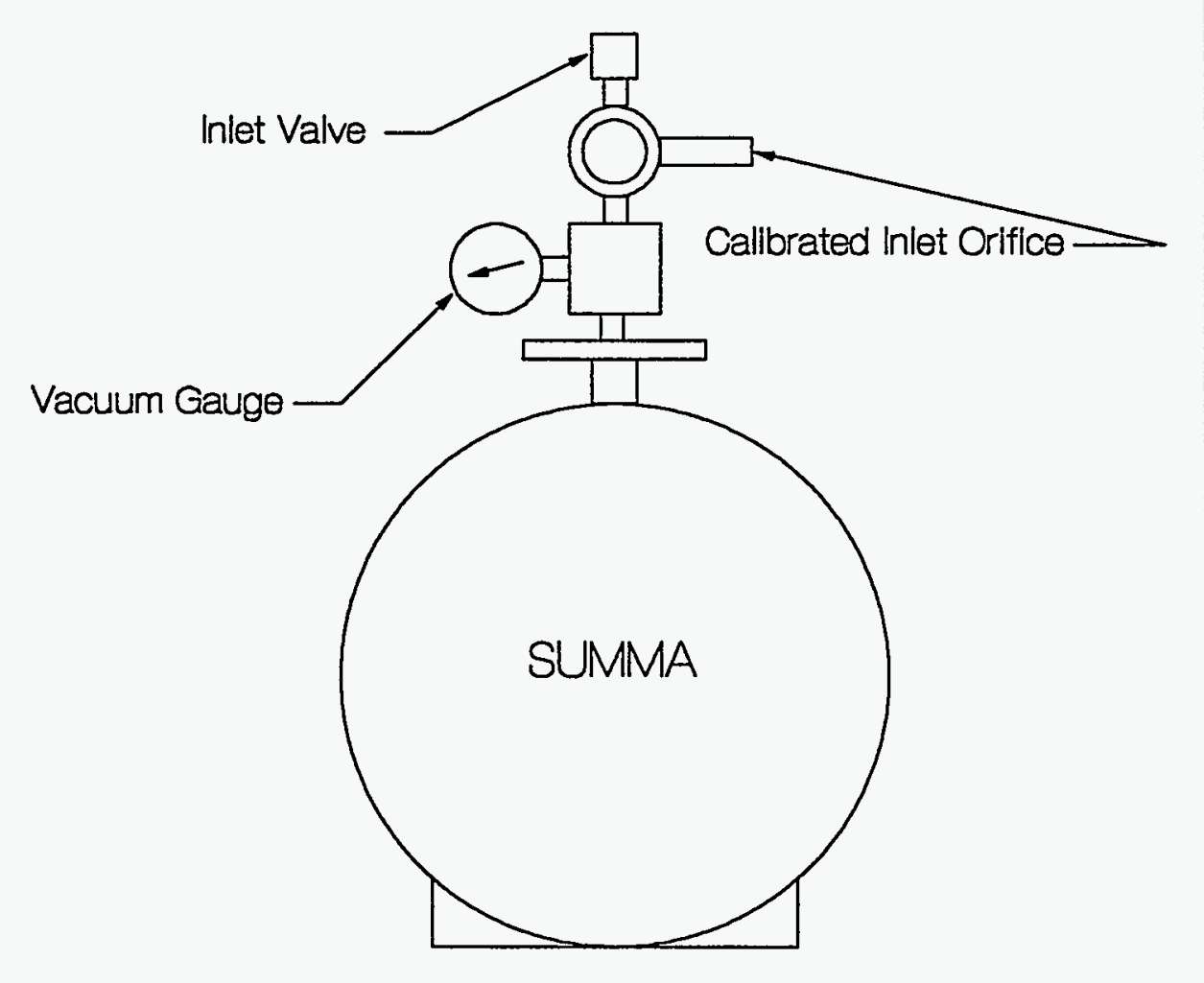

Figure 5-1. Sketch of SUMMA® canister.

3. Record start time of sampling (canister valve and vacuum/pressure gauge valve are opened) and set flow rate in sample logbook.

4. After the desired sampling period (e.g., $5 \mathrm{hrs}$ ), record the current ambient temperature and barometric pressure in the sample logbook.

5. At the end of the sampling period, close the vacuum/pressure gauge valve on the sampler, record the gauge pressure, end sampling time, temperature, and barometric pressure in the sample logbook. Record the pressure gauge reading prior to shipment.

6. Attach a sample tag (with canister number, sample number, location, and date) to the canister. 
7. Prepare (i.e., packaging, documentation) the SUMMA@ canisters.for shipment and send to the appropriate off-site laboratory for analysis.

The FTL (or designated alternate) will check the operation of the sampling system at least once during each sampling event. During this check, the FTL will ensure that each SUMMA® canister is operational. Any adjustments made to the SUMMA® canister shall be noted in the field logbook. In addition, the FTL will conduct a routine safety inspection of the equipment and general area to ensure that safe conditions are maintained. The FTL will note any operational events (e.g., changes in ventilation of building, painting, drum venting, etc.).

\subsubsection{Sample Equipment List}

Sampling device: ·

SUMMA@ canisters

Variflow sampling valves

\section{Other equipment:}

Tripods

Sample tags

Black indelible ink pens

Kimwipes/paper towels

Laboratory request-for-analysis forms

Shipping labels

Chain-of-custody forms and seals

Sample logbook

Shipping logbook

Strapping tape

Masslinn® wipes

Fiberglass tape

\subsubsection{SUMMA@ Canister Maintenance/Decontamination}

The SUMMA@ canisters will be evacuated and certified cleaned by the off-site analytical laboratory prior to shipment to the INEL. The laboratory must provide certification documentation regarding the integrity of the sample canisters, i.e. the sample canisters must be 
checked for leaks, damage and the presence of contaminants (certified clean) according to the guidance provided in method TO-14. Variflow sample flow valves will be cleaned after use by passing nitrogen through the valve while the valve is heated slightly $\left(50^{\circ}\right.$ to $\left.100^{\circ} \mathrm{C}\right)$ by a hot air gun or heating tape.

Only certified canisters will be used for sample collection. The canisters will be considered uncertified if (1) the certification verifying that the canisters are clean is missing, (2) the canister gauge readings do not agree within $25 \%$ of the readings indicated on the canister certification documentation upon receipt by the field personnel, or (3) the canister and/or gauge are damaged.

\subsection{Portable Gas Chromatograph Monitoring}

\subsubsection{Portable Gas Chromatograph Operation Procedures}

The portable GC may be used to provide field screen information. The portable GC operation will be conducted with manufacturer's operational procedures.

\subsubsection{Portable Gas Chromatograph Equipment List}

\section{Sampling device:}

Portable GC

Other equipment:

Battery Pack

Black indelible pens

Zero air carrier gas supply

GC Logbook

Gas cylinder regulators and associated fittings

Tools for assembly, modification and maintenance

Surrogate compounds

Calibration standards

Plastic tubing

Gas tight syringes 


\section{DOCUMENT MANAGEMENT AND SAMPLE HANDLING}

The following sections summarize document management and sample control. Documentation includes all documents used to record field data, sampling procedures, and chain of custody. All documentation and records will be provided to the project manager for filing, record, storage, etc., at the conclusion of the sampling and analysis activities.

\subsection{Pre-Monitoring and Sampling Documentation}

The FTL or designated alternate will ensure that signatures are obtained in the sample and OPFTIR logbook to document that all field team members have completed and fully understand the required reading. Additionally, the radiological work permit must be read, understood, and initialed by all team members.

Before actual field work, a pre-job briefing will be held with attendance required of all team members. At this time, all aspects of the monitoring and sampling efforts will be thoroughly explained and reviewed. Specific duties will be assigned to each team member by the FTL or designated alternate. Attendance at this meeting will be documented in the sample and OP-FTIR logbook.

The project manager or designee, the RWMC Shift Supervisor, and TSA Operations Manager will be notified prior to commencing the intended monitoring or sampling activity.

\subsection{Monitoring and Sampling Documentation}

The FTL or designated alternate will be responsible for ensuring that all information pertaining to the monitoring and sampling project is recorded accurately and completely. The following documentation requirements are to ensure quality control and to ensure proper completion of the chain of custody forms.

\subsubsection{Sample Container Tag}

A tag will be attached in the field to each sample container, using a plastic tie band. Sample tag information includes the sample identification number and analysis type. The date and time of sampling will be recorded in the field on the tag. 


\subsubsection{Sample Identification Number}

A unique sample identification number will be assigned to each sample container. The first three characters will identify the project. The next three identify a specific location with the following two numbers representing a sequence number for a number of samples. The last two characters represent the analysis to be performed (VT $=$ volatile organic compounds). A total of ten characters will be used to identify each sample.

\subsubsection{Custody Seals}

The field staff will be responsible for the proper handling and storage (secured to preclude unauthorized access) of the samples until the samples are delivered to the laboratory. Custody seals will be used to detect unauthorized tampering of samples following sample collection until analysis. The seal will be attached to each shipment container, which will be cardboard boxes, used to store multiple sample containers in such a way that the seal must be broken to gain access to the samples. The seal will contain the following information:

- The signature of the person collecting the sample or other sampling team personnel participating in sample collection

- The date of seal placement.

\subsubsection{Logbooks}

\subsubsection{Sample and OP-FTIR Logbook}

A bound field logbook with consecutively numbered pages will be maintained by field personnel. The FTL or designated alternate will be responsible for retaining and ensuring the use of the logbook. Field logbooks will be used to record sample collection activities and field observations. All logbook entries will be made in permanent black ink, dated, and signed by the individual making the entry (each page). Another sampling or monitoring person present at the site will review the entries and sign and date in the appropriate space.

If an error is made on any document, corrections will be made by drawing a single line through the error and entering the correct information. All corrections will be initialed and dated by the 
individual making the correction. . Pages will not be removed from the logbook and correction fluid will not be used for any reason.

Information logged on a daily basis will include:

- Date and time of monitoring and sampling activity

- Personnel present during monitoring and sampling

- Description of samples

- Quantity and type of sample(s) taken

- Description of sample and monitoring location

- Sample collection and monitoring information; any notable problems or concerns

- All instrument readings and field measurements

- Field observations

- Collector's and monitor's name

- SOW number or lab contract number

All logbooks will be returned to J. G. Jolley at MS 2208 at the conclusion of project.

\subsubsection{Shipping Logbook}

This logbook will contain a description of every sample shipped, including sample number, date collected, laboratory or storage area shipped to, date shipped, chain of custody number, comments, and sample shipping classification. A copy of each chain-of-custody form will be placed in the back pocket of the logbook. 


\subsection{Chain of Custody}

The chain-of-custody record will establish the necessary documentation to trace the sample possession from the time of collection to analysis. Each change of possession will be documented, thus establishing a chain for tracking the handling of samples.

The chain-of-custody record is a two-part record that will be initiated by the field staff after sample collection. One copy of the record will be held in the field file, and the other will accompany the sample to the laboratory, where it will be signed and dated by the laboratory manager or laboratory custodian accepting delivery of the samples. Upon analysis completion, the chain-of-custody record will be returned with the requested analytical information, and placed in the project files.

A minimal number of persons will handle the samples. The appropriate sample identification documents will be completed prior to or immediately following sample collection. If, at any time, the chain of custody is broken, the last person on the chain-of-custody record will be contacted to explain the problem.

The chain-of-custody record will contain the following minimum information:

- Sample number

- Signature of sampler

- $\quad$ Requested analysis

- Date of sample collection

- Any remarks, descriptions, or concerns about the sample

- Date, time, and signature of the person relinquishing or receiving the samples.

- Laboratory Statement of Work number

\subsection{Sample Tracking}

Incoming samples will carry identification numbers. To further identify these samples, the laboratory will assign its own identification numbers, which are normally given consecutively. 
Each sample will be marked with the assigned laboratory number. Both numbers will be recorded in the laboratory sample logbook or computer database. The information on the chainof-custody record, sample tag, and label will be cross-checked at the analytical laboratory.

\subsection{Sample Handling}

\subsubsection{Sample Containers}

All laboratory sample containers will be precleaned and obtained from Southwest Research Institute (SwRI), San Antonio, Texas, an EG\&G Idaho-approved laboratory.

\subsubsection{Sample Preservation}

Preservation of air samples is not necessary. SUMMA@ canisters shall not be refrigerated.

\subsubsection{Transportation of Samples}

The holding time of the air samples is 7 days. All samples will be shipped "priority one/overnight" in accordance with the regulations issued by the Department of Transportation (DOT); 49 CFR 171 through 179; EPA sample handling, packaging, and shipping methods; and 40 CFR 261.

All samples will be packaged and transported in a manner that protects the integrity of the sample and prevents sample leakage. The SUMMA® canisters will be packaged in individual cardboard boxes. These individual packages will be placed in a larger cardboard box and shipped.

After sample collection and packaging in the field, the samples must reach the laboratory intact and in a timely manner. Samples will be packaged and labeled according to DOT shipping requirements.

Samples will be packaged in appropriate shipping containers according to DOE regulations and checked by RCT personnel on site to ensure that radiation readings are at or below acceptable levels at contact.

Transportation of suspected radioactive and/or hazardous samples both on site and off site will be coordinated with EG\&G shipping personnel. These arrangements will be made prior to the 
onset of field sampling activities.

\subsubsection{Field Monitoring for Organic Vapors}

Employee exposure to organic vapors will be monitored at the discretion of IH personnel during sampling activities. Organic vapor measurements will be taken routinely throughout sample collection if significant levels are indicated by the initial survey. Passive dosimeters will be used to monitor personnel exposure during field sampling activities if deemed appropriate by $\mathrm{IH}$. 


\section{ANALYTICAL PROCEDURE}

Samples will be sent to the SwRI for VOCs analyses. The statement of work (SOW), ER-SOW159 , identifies the analytical support required for VOC analyses for samples collected from the RWMC TSA.

In general, analysis of air samples is to be performed by the use of cryofocusing, GC separation, and MS detection. 


\section{CORRECTIVE ACTION}

\subsection{Field Corrective Action}

The initial responsibility for monitoring the quality of field measurements lies with the field personnel. The FTL or designated alternate will be responsible for verifying that all QA procedures are followed. This requires that the FTL or designated alternate assess the correctness of field methods and their ability to meet QA objectives, and make a subjective assessment of the impact that a procedure has on field objectives and subsequent data quality. If a problem occurs that might jeopardize the integrity of the project, cause a QA objective to not be met, or impact data quality, the FTL or designated alternate will immediately notify the project manager (or designated alternate).

The FTL or designated alternate will document the situation, the field objectives affected, the corrective action taken, and the results of that action. Copies of documentation will be provided to the project manager and the project QA officer.

Corrective action will be implemented when the project objectives are not met or when conditions adverse to quality have been identified. Conditions adverse to quality shall be promptly identified and corrected as soon as possible. The identification, cause, and corrective actions to prevent recurrence shall be determined and documented for significant conditions adverse to quality.

\subsection{Laboratory Corrective Action}

The laboratory corrective action plan will be detailed in the laboratory quality program plan. The need for corrective action may come from several sources: equipment malfunctions, failure of internal QC checks, method blank contamination, failure of performance or system assessments, and noncompliance with QA requirements. The SOW outlines requirements for laboratory $\mathrm{QA} / \mathrm{QC}$ and reporting requirements.

\subsection{Assessments}

Normally, at least one performance assessment will be conducted by the QA officer during sampling efforts. EG\&G Idaho will provide performance assessment. 


\subsection{Calibration}

Each piece of equipment shall be identified such that the pertinent calibration information can be retrieved. The equipment shall have an individual calibration $\log$ and be calibrated/standardized prior to use or as a part of the operational use following the manufacturer's recommended procedures for calibration/standardization.

Measuring and testing equipment shall be calibrated at prescribed intervals and/or prior to use. Frequency shall be based upon the type of equipment, inherent stability, manufacturer's recommendations, intended use, and experience.

\subsubsection{Calibration Records}

Records shall be prepared and maintained for each piece of calibrated equipment to indicate that established calibration procedures have been followed. Calibration records for the equipment controlled by the various laboratories, offices, and groups shall be maintained by the respective organizations. A copy of the instrument logbook that indicates the calibration status shall be on file when the samples are analyzed.

\subsubsection{Calibration Failure}

Field and laboratory equipment found to be out of calibration shall be recalibrated in accordance with the requirements of this section. When test equipment is found to be out of calibration, damaged, lost, or stolen, an evaluation shall be made to ascertain the validity of previous inspection or test results, and the acceptability of components inspected and/or tested since the last calibration check. When it is necessary to ensure the acceptability of suspect items, the originally required inspections and/or tests shall be repeated using properly calibrated equipment. Suspect items on which a questionable device was used shall be listed in a nonconformance report or deficiency notice, as applicable. Test equipment consistently found to be out of calibration shall be repaired or replaced. Inspection and test reports shall include identification of the test equipment used to perform the inspection or test.

\subsection{Data Validation}

Sampling data will be evaluated by the Sample Management Office personnel against the QC limits specified in ER-SOW-159. The SOW specifies information and guidance specific to the 
samples to be analyzed and data reporting forms to be used.

OP-FTIR data will be evaluated by an independent technical expert as a function of the criteria contained in the Draft U.S EPA "Field Standard Operating Procedure for the Use of Open-Path FTIR Spectroscopy at Hazardous Waste Sites" (March 1992). 


\section{WASTE MINIMIZATION}

Waste minimization has been addressed, in general, in the RWMC Waste Minimization Plan, 1993; however, no wastes are anticipated to be generated during the field sampling activity. There will be minor releases of the surrogate compounds (calibration gases) during the monitoring activities. It is not anticipated that the total volume will exceed 10 liters per day. 


\section{HEALTH AND SAFETY CONSIDERATIONS}

Health and Safety aspects of work to be conducted in accordance with this Monitoring Plan are covered by Waste Storage Facilities Safety Analysis Report (EGG-WM-10774). The following provides additional information and clarification to ensure the health and well being of field personnel.

The FTL or designated alternate will ensure that a radiological work permit is used for this sampling activity and that the appropriate support personnel are informed of the planned sampling date, time, and the need for any required support.

A brief daily safety meeting covering applicable task-specific health and safety issues will be conducted prior to sampling. Potential accident/emergency scenarios and corresponding responses will be included in this briefing. The FTL or designated alternate will verify attendance at the meeting by obtaining the signatures of all team members in the corresponding logbooks.

Team members must be trained as per 29 CFR Part 1910.120 (40 hours of OSHA hazardous waste operations training), have a current, valid health and safety permit card (Form EG\&G2580), have current radiation worker training, and must initially wear Level D protection.

Eating, drinking, chewing gum or tobacco, smoking, or any other practice that increases the probability of hand-to-mouth transfer and ingestion of potentially hazardous/toxic material is prohibited during monitoring and sampling activities. Hand and forearms must be thoroughly washed upon leaving the work area and before eating, drinking, smoking, or using the rest room.

Contact with potentially contaminated surfaces will be avoided whenever possible. Personnel should avoid leaning, sitting, or placing equipment on drums, containers, vehicles, or the ground unless otherwise required.

Sample collection operations will be suspended if an accident occurs, or if the FTL or designated alternate determines that conditions are adversely affecting operational safety.

No instruments, tools, or protective gear used in the monitoring and sampling activities will be removed from the immediate vicinity of the monitoring and sampling areas until they are surveyed and decontaminated as necessary, disposed of, or until controls are in place to avoid exposure during transport or storage. The shift supervisor will be notified of ingress and egress of all monitoring and sampling personnel to the sampling site.

If evacuation is necessary, for any reason, the proper evacuation procedures set forth in the 
EG\&G Emergency A ction Plan will be followed. Evacuation procedures will be discussed in the pre-job briefing.

\subsection{Radioactive Spill Control}

Contamination in uncontrolled areas is designated as a "spill"; if a spill is noticed, task operations personnel shall initiate the SWIMS approach;

- Stop or secure the operation causing the spill

- Warn area personnel and notify an RCT

- Isolate the area and spill if possible

- Minimize exposure to the contamination

- Secure any unfiltered ventilation paths, and have an RCT survey the extent of the spill

\subsection{Medical Surveillance Program}

The INEL Occupational Medical Program (OMP) provides medical advice and service to all INEL employees and employers. The INEL OMP resides in the health and medical program organization of EG\&G Idaho, and their activities are required and authorized by DOE Order 5480.8 and 29 CFR 1910.120. The OMP helps to ensure compliance with OSHA and other regulations. These regulations require medical surveillance of workers exposed above threshold limit values $30+$ days per year, those wearing respiratory protection $30+$ days per year, those injured or overexposed from emergency incidents, and other personnel involved in the handling of hazardous materials. Medical advice and treatment can be obtained by visiting INEL Building CFA-603 or calling 526-2356. 


\subsection{Medical Surveillance Program}

- Ambulance $\quad 777$

- Fire - 777

- Security 777

- Warning Communications Center (WCC) 777

- Area Emergency Action Director 526-6260

- Monitoring Field Team Leader (FTL) K. J. Galloway 526-0902

- ES\&Q Project Manager J. M. Jackson 526-7929

- First Aid (CFA-603) 526-2356

- Assistant Monitoring Field Team Leader $\quad$ M. R. Hankins 526-8321

- Monitoring Field Technical Leader J. G. Jolley 526-8036

- Occupational Medical Program 526-2356

- Sample Management Office (SMO) K. J. Izbicki 526-1474

- RWMC Industrial Hygiene T. O. Bodily 526-7964

$\begin{array}{lll}\text { - RWMC Industrial Safety } & \text { D. K. Gray 526-7370 }\end{array}$

- RWMC Project Manager M. J. Sherick 526-4212

- RWMC Radiological Engineering M. K. Branter 526-2486

- RWMC Shift Supervisor T. D. Cline 526-2767

- RWMC/SWEPP.Operations Unit Manager J. R. Bishoff 526-2766

NOTE: This emergency reference list will be kept in the monitoring or designated alternate logbooks. Initial notification to the WCC or the shift manager may be made using radio communications. 


\section{HAZARD EVALUATION}

Potential hazards during monitoring and sampling activities include the presence of VOCs, radiological contamination, and hazardous materials. Site personnel should constantly look for potential safety hazards and immediately inform their supervisors of any new hazards so that mitigative action can be taken.

\subsection{Chemical Hazards}

Chemical hazards to the field team exist when gaseous, liquid, or solid samples from the investigation site contact human tissue. Every effort will be made to avoid direct contact with any chemical hazards at the site.

\subsubsection{Routes of Chemical Exposure}

The field monitoring and sampling team may be exposed to chemical vapors or particulates through inhalation, ingestion, and/or absorption (skin and eye contact).

- Respiratory system contact with chemical vapors or particulates may occur when workers fail to properly use or handle associated chemicals required for the monitoring.

- Gastrointestinal system contact with samples may occur when workers do not pay attention to personal hygiene practices designed to reduce the chance of ingesting site contaminants (e.g., washing hands thoroughly before smoking, eating, or drinking after leaving the site).

NOTE: Although ingestion should be the least significant route of exposure at a site, it is important to be aware of how this type of exposure can occur. Deliberate ingestion of chemicals is unlikely; however, personal habits such as chewing gum or tobacco, drinking, eating, smoking cigarettes, and applying cosmetics in the site area may provide a route of entry for chemicals. None of the above is allowed while in controlled areas. Consumption of fluids or food will have to be done in an approved eating area. 
- Skin contact with solid, liquid, or gaseous chemicals may occur when a worker does not wear proper protective clothing during monitoring and sampling activities or when sample preparation and packing is performed carelessly.

- Eye contact with solid, liquid, or gaseous chemicals may occur when a worker does not wear proper eye protection or when dirty hands are used to rub an eye.

\subsubsection{Indicators of Chemical Exposure}

Indicators of chemical exposure observable by others include:

- Changes in complexion, skin discoloration

- Lack of coordination

- Changes in demeanor

- Excessive salivation, pupillary response

- Changes in speech pattern

- Change in personality

- $\quad$ Vomiting

- Paroxysmal coughing

- $\quad$ Seizures.

Indicators of chemical exposure not observable by others include:

- Headaches

- Dizziness

- $\quad$ Blurred vision

- Cramps 
- Irritation of eyes, skin, or respiratory tract.

\subsubsection{Field Radiation Screening Procedures}

Qualified RWMC RCTs will perform sample and equipment radiological screening in the field for shipping purposes. Direct radiation instrument measurements will be taken to protect personnel and to determine shipping and handling requirements. All samples will be measured for direct radiation using the appropriate instrument provided by the RCT. Results will be recorded in the field logbook and on the sample tag. Additional tags may be required per the RCT's instructions. The specific procedures for field measurements will depend on the type and brand of instrument chosen. Instruments will be calibrated prior to field use, and used by trained RCTs to ensure the safety of field and laboratory personnel. Samples will be handled according to guidance provided by the RCT or radiological engineer.

\subsection{Physical Hazards}

The field team can be exposed to a number of physical hazards during this project. Physical hazards that may be encountered are:

- $\quad$ Fire and explosion

- $\quad$ Ionizing radiation

- Industrial safety hazards

- Electrical hazards

- Heat stress

- Work stress.

General considerations are discussed below.

\subsubsection{Ionizing Radiation}

Radioactive contamination may be present at this site. The RCT assigned by RWMC will 
determine the need for and the frequency of additional surveys.

\subsubsection{Industrial Safety Hazards}

RWMC may contain numerous safety hazards, such as:

- Existing hazardous objects

- Lifting heavy objects

- Moving equipment and falling objects.

\subsubsection{Lifting Heavy Objects}

Field team members may be exposed to injury caused by lifting heavy objects. All field team members should be trained in the proper method of lifting heavy equipment and cautioned against lifting objects that are too heavy for one person. Mechanical and hydraulic assists will be used whenever possible to minimize lifting dangers.

\subsubsection{Personal Protective Equipment}

Wearing PPE reduces a worker's ability to move freely and hear directions and noise that might indicate a hazard. Protective equipment can impair a worker's agility, hearing, and vision, which can result in an increased risk of falling over objects, striking objects, or being struck by them. All workers wearing PPE will be made aware of the potential increase in risk of physical hazards. PPE can also elevate the risk of heat stress and possibly work stress.

\subsubsection{Heat Stress}

During the project, workers may be required to wear protective clothing that insulates the body, which could result in adverse health effects if not correctly managed. High ambient temperatures can result in various symptoms, including heat fatigue and physical discomfort, all stemming from the increase of body temperature. The FTL, designated alternate, and field team members must be alert for the signs and symptoms of heat stress and act accordingly to preserve the alert and safe work practices necessary for this operation. 
Field team members will be observed for the following signs and symptoms of heat stress:

- Nausea

- $\quad$ Fatigue

- $\quad$ Dizziness/fainting

- $\quad$ Profuse sweating

- Skin color change (pale, muddy, hectic flush).

Any team member who exhibits any of these symptoms will be removed immediately from field work and allowed to rest. The team member shall be taken to a medical facility if the symptoms persist or when required by an appropriate responsible official or person.

Field team members will be observed for the signs of heat stroke, including any change in mental status such as confusion or visual changes, or hot dry clammy skin or red skin. Any team member who exhibits these symptoms will be immediately evacuated to the nearest medical facility without delay.

Many methods are available to minimize the effects of heat stress besides the establishment of a work/rest regimen. During breaks, each worker will be at rest and able to drink cool drinks in approved eating areas. Protective clothing may be removed, and breaks will be taken when needed.

\subsubsection{Cold Stress}

The Waste Storage Facilities are not temperature regulated; therefore, exposure to low temperatures may be a factor if work is done in the winter months, in inclement weather, or in the evening hours. The FTL, designated alternate, and field team members must be alert for the signs and symptoms of cold stress and act accordingly to preserve the alert and safe work practices necessary for this operation.

Field team members will be observed for the following signs and symptoms of cold stress:

- Drowsiness 
- $\quad$ Mumbling/slurred speech

- Trouble making decisions

- Difficulty performing tasks

- Loss of coordination/weakness.

Any team member who exhibits these symptoms will be removed immediately from field work. The team member shall be taken to a medical facility if the symptoms persist or when required by an appropriate responsible official or person.

\subsubsection{Decontamination}

The decontamination of tools, equipment, and/or personnel to remove contamination generated by the activities identified in this document has the potential for spreading contamination and increasing the exposure to personnel if care is not exercised when the decontamination activities are taking place. If possible, the contaminated tools, equipment, or personnel will be removed to a separate and well ventilated area.

\subsubsection{Work Stress}

The FTL or designated alternate and IH assume the responsibility to use good judgment in the assignment of personnel fatigued by excessive hours of work in psychologically and possibly physiologically stressful environments. 


\section{REFERENCES}

EG\&G Idaho, Inc., Quality Manual.

EG\&G Idaho, Inc., 1993, Radioactive Waste Management Complex Waste Minimization Plan, WM-PD-89008, Rev. 4, March 1993.

EG\&G Idaho, Inc., 1994, Radioactive Waste Management Complex Safety Analysis Report, EGG-WM-10881, Rev. 1.

EPA (U. S. Environmental Protection Agency), 1988, Compendium of Methods for the Determination of Toxic Organic Compounds in Ambient Air, EPA/600/4-89/017, June 1988.

Draft EPA (U. S. Environmental Protection Agency), 1992, Field Standard Operating Procedure for the Use of Open-Path FTIR Spectroscopy at Hazardous Waste Sites, March 1992.

Childers, J. W. and Russwurm, G. M., 1993, FT-IR Open-Path Monitoring Guidance Document, prepared for U. S. Environmental Protection Agency, SP-4423-93-09, March 1993.

Occupational Safety and Health Guidance Manual for Hazardous Waste Site Activities, October 1985. 